Prof. Dr. Bülent Özer

MSGSÜ Mimarlkk Fakültesi

Mimarlık Bölümü

\title{
Prof. Muammer Onat Müstesna Bir Kişilik
}

Muammer'i 1960'lı yılların başlarında, belki 1961, belki de 1962'de tanıdım. Daha doğrusu, yalnızca Muammer'i değil, daima birlikte gezip dolaştığı değerli Dost İlhami Turan'ı da. Bu tanışıklık ve onu izleyen kaynaşma ne İTÜ'de, ne GSA'da, ne de, o zamanki adıyla, Tatbikî Güzel Sanatlar'da gerçekleşti. Bizim tanışıp samimîleştiğimiz yer TürkAlman Kültür Kurulu'nun Tünel'deki Müeyyet İşhanı'nın birinci katındaki merkeziydi.

O yıllarda benim en yoğun işbirliği yaptığım kurum rahmetli Dr. Robert Anhegger'in yönetimindeki Türk-Alman Kültür Merkezi'ydi. Peşpeşe konferanslar verdiğim, sergiler düzenlediğim bu mekânda Muammer-İlhami ikilisi daimî müşterilerimdi (!). Genellikle, faaliyetlerin bitiminde birlikte İstiklâl Caddesi'ne çıkar, sohbet ederek Taksim'e yürüdükten sonra ya evlerimizin yolunu tutar, ya da o sırada kararlaştırdığımız bir yerde yemek yeme zevkine kaptırırdık kendimizi. Bu yakınlık ve karşılıklı sempati günümüze kadar sürüp gelmiştir.

Diyeceğim odur ki, benim "cevher"i keşfedişim bir hayli eskiye dayanır. Sevgili Muammer ender rastlanan düzeydeki zekâsı, Galatasaraylılık damgası taşıyan sağlam kültürü, her yöne, her konuya açık hassas antenleriyle, ve bu kalitelerini kucaklayan iyimserlik ve neşesiyle son derece ilginç bir kişilik oluşturmuştur. Ve, bu hamura sahip bir kimsenin en çok sanat dallarında, özellikle de mimarlıkta yaratıcı ve öğretici olarak başarıya ulaşması beklenebilirdi. Muammer'in çift yönlü profesyonel hayatı bu tahmini yüzde yüz doğrulamıştır. Ve, ister kendi yaptıkları, isterse de öğrencilerine yaptırdıkları daima olumlu bir ayrıcalığın göstergesi olmuşlardır.

Tipkı ince buluşları ve esprileri gibi... 